\title{
Oral yeasts infection in children
}

\author{
Niem N. Jammil*, Manahil M. Yehia** \\ * Department of Microbiology, College of Nineveh Medicine, **Department of Microbiology, College of \\ Medicine, University of Mosul, Iraq. Correspondence: dr.manahil2012@yahoo.com
}

\section{Received $\quad$ Accepted \\ 27.5.2013 18.11.2013}

\section{ABSTRACT}

Objective: The study was designed to identify the yeasts which cause oral thrush in children, in addition to other sources including the teat of bottle, nipple of breast, pacifier, and vaginal swabs from mothers of newborn to detect the source of infection.

Patients and Methods: One hundred and twenty clinically diagnosed child with oral yeast infection were enrolled during this study. The clinical specimens were collected from Dec. 2012 - May 2013, and included (120) oral swabs from infected children and (60) swabs from healthy children. In addition to (46) swabs from teat of bottle feeding babies, (37) swabs from nipple of breast feeding mothers, (20) swabs from pacifier, and (17) swabs from mother's vagina of newborn. The identification process employed direct examination, culture in different media, germ tube, chlamydospore formation and API - $20 \mathrm{C}$ system tests .

Results: Candida albicans is the main isolate from both patients and control group (90.1\% ; 78.3\% respectively), and also from the other sources . Moreover, other yeasts isolated from the patients only including Cryptococcus laurentii (3.9\%) and Saccharomyces cerevisiae (1\%) .

Conclusions: Candida albicans and other yeasts were isolated from the oral lesions and other sources indicating that the infection transmitted for and back to the infected children.

Keywords: Oral yeast, infection.

الأهداف: صمدت هذه الدراسة لتميز الخمائر التي تسبب النُلاق الفموي عند الأطفال ومن أطفال أصحاء يمنلون مجموعة السيطرة ، بالإضافة إلى عزل الخمائر من حلمة قناني الرضاعة الاصطناعية وحلمة ثذي الأمهات المرضعانقالاً هُ "اية بالإضافة إلى عزلها من مهبل أُمهات الأطفال حديثي الولادة .

المرضى وطرائق العمل: تضمنت الدراسة 120 طفل مصاب بالُّلاق الفموي • جمعت العينات السريرية ما بين شهر كانون الأول 2012 - أيار 2013 ـ شملت الدراسة (120) مسحة فموية من الأطفال المصابين و (60) مسحة من أطفال أصحاء بالإضافة إلى (46) مسحة من الحلمة لقناني الرضاعة الاصطناعية و (37) مسحة من حلمة ثدي الأمهات المرضعات و (20) منحة من الأً أية بالإضافة إلى (17) مسحة من مهيل أمهات

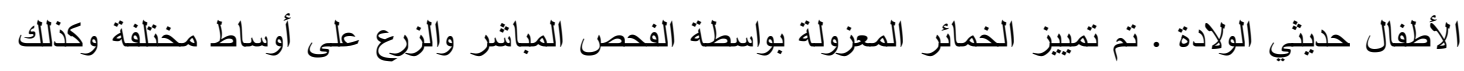

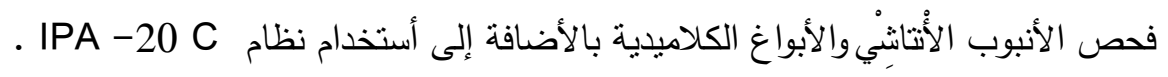


النتائج: كانت Candida albicans أهم العزلات من المصابين والأصحاء (90,1\% و 78,3\% بالتعاقب) وكنلك من المصادر الأخرى ـ كذلك عزلت خمائر أخرى من المرضى وهي ( Cryptococcus laurentii . \%1), Saccharomyces cerecvisiae (9\%3, الاستنتاج: عزل المبيضات البيضاء والخمائر الأخرى من النُلاق الفموي والمصادر الأخرى تثبت بأن الأصابة

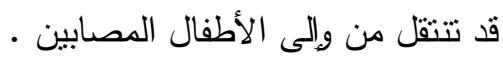

$\mathbf{y}$ east - like fungi establish a biological link with the host which guarantees their saprophytic condition by establishing an ecological equilibrium denoted "amphibiosis" ${ }^{1}$. When this equilibrium is broken due to different endogenous and/or exogenous factors these amphibionts behave as opportunistic microorganisms, eventually causing oral infections which, if unresolved, may become generalized, leading to more severe mycoses ${ }^{2}$.

Oral candidiasis is a sign of impaired local or systemic defense mechanisms. Reduced saliva secretion, deficiencies of humeral or cell mediated immunity, local mucosal diseases and the use of wide spectrum antibiotics are predisposing factors ${ }^{3}$. In the newborn, colonization usually occurs from the mothers vaginal flora or other exogenous sources ${ }^{4}$. Moreover, thrush occurs more frequently in bottle - fed than in breast - fed babies and the lesions not frequently spread to the pharynx and even esophagus ${ }^{5}$. Also, some factors alter the host's defenses and allows yeasts to colonize the nipple of breast feeding mothers at pathological levels such as diabetes, corticosteroids and antibiotic therapy ${ }^{6}$.

The development of oral candidiasis is the result of an imbalance between fungal virulence factors and host defenses 7 . Fungal virulence factors are necessary for the transition from colonization to infection. The first step is epithelial adhesion, involving protein and glycoprotein adhesions, the second step is fungal replication and tissue invasion, based on the capabilities of filametation of Candida albicans, and the secretion of phospholipase and proteases $^{8}$.

The aim of this study to identify the yeasts which cause oral infection and to determine the source of infection and risk factors which lead to such infection

\section{Materials and Methods \\ Patients and controls}

The study included 120 child clinically diagnosed with oral thrush. The male were $59(49.2 \%)$ and female were 61 $(50.8 \%)$. The age of the studied children ranged from 2 days -12 years.

The control group comprised of 60 healthy child. They were 29 (48.3\%) males and 31 (51.7\%) females. Their age ranged between 3 days -12 years. These children were sex and age matches with the infected children. The patients and control group were interviewed and information about possible recognizable risk factors for acquisition of yeasts were recorded using a questionnaire. 


\section{Collection and processing of samples}

Two hundred and forty swabs were collected during six months from December 2012 to May 2013. One hundred and twenty oral swabs were taken from children clinically diagnosed with oral thrush, 46 swabs from teat of bottle feeding babies, 37 swabs from nipple of breast feeding mothers, 20 swabs from pacifier, and 17 swabs were taken from mother vagina of newborn in the neonatal Care Units.

All the samples collected from the children admitted to Consultative Clinics and Medical wards of Ibn Sina and Ibn - Al-Ather Teaching Hospitals, in addition to the neonatal Care Unit of Al-batool Teaching Hospital.

From the 60 apparently healthy child, the oral swabs were processed as those from the patients.

Early morning swabs in sterile containers were collected from all patients and other sources. The swabs brought to the laboratory of Microbiology Department immediately

Each swab was cultured on Sabouraud dextrose agar with $\mathrm{P} / \mathrm{S}$ and brain heart infusion (BHI) blood agar, then incubated at $37^{\circ} \mathrm{C}$ for $2-3$ days. A direct $\mathrm{KOH}$ mount and/or Gram stained slides were also prepared from each swab and examined immediately for the presence of yeasts.

\section{Identification of the isolates}

Germ tube test, morphology on corneal agar Tween 80 and Lactophenol mount, in addition to the commercial test API - $20 \mathrm{C}$ system were used for identification of the yeast species. $T$ he

\section{Results}

The present study included 120 clinically diagnosed child with oral yeast infection. Their age ranging between 2 days -12 (mean $2.28 \pm$ SE 0.30) years, and were categorized into 4 age groups. The male forming $49.2 \%$ while the female were $50.8 \%$. The higher percentage of infection appeared in infants followed by toddles with no significant difference between the male and female. The control group included 60 healthy child who were sex (48.3\% male; $51.7 \%$ female) and age (mean $2.58 \pm \mathrm{SE}$ 0.45) years matches with the patients (Table1).

The total number of swabs collected were 240. Those which showed positive yeast isolates were 102 from oral thrush, 23 from bottle teats, 14 from breast nipples, 8 from pacifiers, and 1 from mother's vagina (Table 2).

The type of feeding of the studied children were bottle, breast, mixed, usual, and intravenous fluid (Table 3).

The risk factors recorded for the infected children were: gastroenteritis, cancer, congenital heart diseases, malnutrition, jaundice, meningitis, sepsis, and other miscellaneous factors. The higher incidence of infection were among those with gastroenteritis (39.2\%), Table 4.

The types of yeasts isolated from oral lesions and those from the control group were presented in Table 5. Candida albicans is the main isolate from both the patients and control group (90.1\% ; 78.3\% respectively). The non Candida albicans Candida (NCAC) isolates from both the patients and control group respectively were : $C$. tropicalis $(2 \%$; $4.3 \%)$, C. parapsilosis ( $2 \% ; 4.3 \%)$, and $C$. guilliermondii $\quad(1 \% ; 8.8 \%)$ respectively. Candida luistaniae isolated from one sample mixed with 
C. parapsilosis. Moreover, Other yeasts isolated from the patients only were Cryptococcus Laurentii (3.9\%) and Saccharomyces cerevisiae (1\%) . Rhodotorula rubra and Trichosporon asahii isolated from samples mixed with $C$. albicans. On the other hand, the yeasts isolated from other sources were recorded in Table 6, showing that C. albicans is the main isolate.

Table 1. The age and gender of the infected children and control group

\begin{tabular}{|c|c|c|c|c|c|c|c|c|c|c|c|c|}
\hline \multirow{4}{*}{$\begin{array}{c}\text { Age groups } \\
\text { (years) }\end{array}$} & \multicolumn{12}{|c|}{ Gender } \\
\hline & \multicolumn{6}{|c|}{ Patients } & \multicolumn{6}{|c|}{ Control } \\
\hline & \multicolumn{2}{|c|}{ Total } & \multicolumn{2}{|c|}{ Male } & \multicolumn{2}{|c|}{ Female } & \multicolumn{2}{|c|}{ Total } & \multicolumn{2}{|c|}{ Male } & \multicolumn{2}{|c|}{ Female } \\
\hline & No. & $\%$ & No. & $\%$ & No. & $\%$ & No. & $\%$ & No. & $\%$ & No & $\%$ \\
\hline $\begin{array}{c}\text { Infants } \\
2 \text { day - } 1 \text { year }\end{array}$ & 62 & 51.7 & 32 & 26.6 & 30 & 25.0 & 31 & 51.7 & 16 & 26.7 & 15 & 25.0 \\
\hline $\begin{array}{c}\text { Toddlers } \\
>1-4 \text { years }\end{array}$ & 34 & 28.3 & 17 & 14.2 & 17 & 14.2 & 16 & 26.7 & 8 & 13.3 & 8 & 13.3 \\
\hline $\begin{array}{c}\text { Preschool } \\
>4-6 \text { years }\end{array}$ & 9 & 7.5 & 5 & 4.2 & 4 & 3.3 & 5 & 8.3 & 2 & 3.3 & 3 & 5.0 \\
\hline $\begin{array}{c}\text { School } \\
>6-12 \text { years }\end{array}$ & 15 & 12.5 & 5 & 4.2 & 10 & 8.3 & 8 & 13.3 & 3 & 5.0 & 5 & 8.3 \\
\hline Total & 120 & $\begin{array}{c}100 . \\
0\end{array}$ & 59 & 49.2 & 61 & 50.8 & 60 & 100.0 & 29 & 48.3 & 31 & 51.7 \\
\hline
\end{tabular}

Table 2. The number of swabs collected from different sources and the positive results for the presence of yeasts

\begin{tabular}{|l|c|c|}
\hline \multicolumn{1}{|c|}{ Swabs taken from } & No. of samples & Positive samples \\
\hline Oral thrush & 120 & 102 \\
\hline Bottle teat & 46 & 23 \\
\hline Breast nipple & 37 & 14 \\
\hline Pacifier & 20 & 8 \\
\hline Vagina & 17 & 1 \\
\hline Total & 240 & 148 \\
\hline
\end{tabular}


Table 3. The correlation between the type of feeding and oral infection

\begin{tabular}{|c|c|c|}
\hline \multirow{2}{*}{ Type of feeding } & \multicolumn{2}{|c|}{ Infected children } \\
\cline { 2 - 3 } & No. & $\%$ \\
\hline Bottle & 28 & 23.3 \\
\hline Breast & 19 & 15.8 \\
\hline Mixed & 18 & 15.0 \\
\hline Usual feeding & 52 & 43.4 \\
\hline I.V* fluid & 3 & 2.5 \\
\hline Total & 120 & 100 \\
\hline
\end{tabular}

*I.V = intravenous

Table 4. The risk factors that predispose to oral yeast infection.

\begin{tabular}{|l|c|c|}
\hline \multirow{2}{*}{\multicolumn{1}{|c|}{ Risk factors }} & \multicolumn{2}{|c|}{ Infected children } \\
\cline { 2 - 3 } & No. & $\%$ \\
\hline Gastroenteritis & 47 & 39.2 \\
\hline Cancer & 19 & 15.8 \\
\hline Congenital heart diseases & 13 & 10.8 \\
\hline Malnutrition & 10 & 8.4 \\
\hline Jaundice & 7 & 5.8 \\
\hline Meningitis & 7 & 5.8 \\
\hline Sepsis & 6 & 5.0 \\
\hline Miscellaneous factors $*$ & 11 & 9.2 \\
\hline Total & 120 & 100 \\
\hline
\end{tabular}

*Miscellaneous factors : Thalacemia (1) ; Premature (2) ; Diabetes mellitus (1) ; Renal failure (2); Steroid therapy (4) . 
Table 5. Types of yeasts isolated from patients and control group.

\begin{tabular}{|l|c|c|c|c|}
\hline \multirow{2}{*}{ Type of yeasts } & \multicolumn{5}{|c|}{ Isolated yeasts } \\
\cline { 2 - 5 } & \multicolumn{2}{|c|}{ Patients } & \multicolumn{2}{c|}{ Control } \\
\cline { 2 - 5 } & No. & $\%$ & No. & $\%$ \\
\hline C. albicans* & 92 & 90.1 & 18 & 78.3 \\
\hline C. tropicalis & 2 & 2.0 & 1 & 4.3 \\
\hline C. parapsilosis $* *$ & 2 & 2.0 & 1 & 4.3 \\
\hline C. guilliermondii & 1 & 1.0 & 2 & 8.8 \\
\hline C. luistaniae & & & 1 & 4.3 \\
\hline Cr. laurentii & 4 & 3.9 & & \\
\hline S. cerevisiae & 1 & 1.0 & & 100 \\
\hline Total & 102 & 100 & 23 & \\
\hline
\end{tabular}

$C=$ Candida $; C r=$ Cryptococcus $; S=$ Saccharomyces.

* 3 species mixed with other yeast: 2 with Rodotorula rubra, and

** one species mixed with C.luistaniae.

Table 6. The number and types of yeasts isolated from different sources which have a relation to the infected children.

\begin{tabular}{|l|c|l|c|}
\hline \multicolumn{1}{|c|}{ Source of samples } & $\begin{array}{c}\text { Total } \\
\text { isolates }\end{array}$ & \multicolumn{1}{|c|}{ Type of yeasts } & No. \\
\hline Bottle teat & 23 & C. albicans & 17 \\
& & C. tropicalis & 1 \\
& & C. parapsilosis & 1 \\
& & C. guilliermondii & 1 \\
& & Cr.laurentii & 2 \\
& & S. cerevisiae & 1 \\
\hline Breast nipple & 14 & C. albicans & 13 \\
Pacifier & 8 & C. parapsilosis & 1 \\
\hline Vaginal swab & 1 & C. albicans & 7 \\
\hline
\end{tabular}

\section{Discussion}

Thrush is a fungal infection of any of the Candida species, also commonly referred to as a yeast infection. The oral thrush is superficial infection of mucous membrane characterized by white adherent patches of pseudomycelium which frequently involves lesions, sores, fissures and ulcers in the mouth which could either 
acute or chronic ${ }^{5}$. The clinical picture of the lesions in the studied patients showed white patches with severe or moderate form.

The higher percentage of infection during the study appeared in children less than one year old. This confirmed by a previous studies mentioned that oral candidiasis is more frequently encountered in infant 9 . Moreover, Nneka and Ebele (2005) reported that oral candidiasis occurred more in younger children than in older children, and there was a significant difference between them. On the other hand, we not found a difference between male and female children in being susceptible to the oral thrush as reported by other investigators 5 ....

A higher percentage $(23.3 \%)$ was recorded during the study among artificially fed babies than breast fed $(15.8 \%)$ which is in consistent with other reports that oral thrush occur more frequently in bottle - fed than in breast - fed babies ${ }^{5,9}$. Other investigators reported that neither breast nor bottle feeding favored development of oral candidiasis ${ }^{10,11}$. ... All the studied cases of oral thrush have a predisposing factors mainly gastroenteritis $(39.2 \%)$ followed by cancer $(15.8 \%)$. Oral candidiasis is an opportunistic infection, it is expected that medically compromised patients are at greater risk for such an infection $^{12}$. Many factors can predispose certain individuals to develop oral candidiasis as reported by Gonzalez- Gravina and coworkers ${ }^{13}$ (2007) that oral thrush represents a serious problem for children with cancer. Other mentioned that Candida infection may be a complication of antibiotics therapy when sensitive organisms are destroyed or for corticosteroid therapy when resistance to infection may be diminished ${ }^{14}$. Moreover, Rowen and coworkers 15 (1994) reported that occurrence of Candida particularly with extremely low birth weight premature infants and poorly nourished patients ${ }^{16}$.

The main isolate among Candida species during the study is Candida albicans from both the infected children and control group (90.1\% ; $78.3 \%$ ) respectively. Other NCAC species isolated were $C$. tropicalis $(2 \% ; 4.3 \%), C$. parapsilosis $(2 \% ; 4.3 \%)$, and C.guilliermondii $(1 \% ; 8.8 \%)$ from patients and control group respectively while one isolate of $C$. lusitaniae (4.3\%) from the control group only. Furthermore, three isolates of Candida albicans from the patients mixed with Rhodotorula rubra and Trichosporon asahii . Candida species are the most common opportunistic fungal pathogen in humans and $C$. albicans being the most prevalent pathogen in mucosal and systemic infection ${ }^{17,18}$. Castilho and Rocha ${ }^{19}$ (2009) reported that $C$. albicans is the most common species isolated from the oral cavity in both healthy and diseased in $60 \%-80 \%$ of the cases. Other species responsible for oral infection have also been identified including C. krusei, C. parapsilosis, C.tropicalis, and C. guillermondii $^{9.20 .21}$. The role of NCAC have become increasingly important especially in high risk patients ${ }^{4}$. Yeast not belonging to the genus Candida such as Rhodotorula and Saccharomyces cereviciae are sometimes found in the oral cavity but these are not known to cause oral infection $^{22}$. 
During the study, C. albicans mainly and other Candida species isolated from the bottle teat, breast nipple, pacifier used by the infants and mother vagina of the newborn. The isolation of the same Candida species from oral lesion and the mentioned items indicate that the infection transmitted for and back to and from the children. Different studies reported about the source of infections. Many researchers have investigated the factors that predispose nursing mothers to nipple candidiasis although an association between oral thrush in infants and nipple candidiasis in mother has been reported ${ }^{23},{ }^{24}$. The infants can pass the infection to their mother during breast feeding, and the infection may then pass back and forth between mother's breast and baby's mouth $^{25}$. Moreover, the use of pacifier which can be a mode of inoculation and reinfection if not properly disinfected after a diagnosis of moniliasis $^{26}$.

\section{References}

1. Azevedo RVP, Komesu MC, Candido RC, et al. Candida species in the oral cavity with and without lesion: Maximal inhibitory dilution of propolis and periogard. Rev de Microbiol 1991;30:335-41.

2. Budtz-Jorgensen E. Etiology, pathogenesis, therapy, and prophylaxis of oral yeast infections. Acta Odontol Scand 1990;48:61-9.

3. Rautemaa R, Rusanen P, Richardson $M$, et al. Optimal sampling site for mucosal candidosis in the oral cancer patients is the labial sulcus. $\mathrm{J}$ Med Microbiol. 2006;55:1447.
4. Meurman JH, Siikala E, Richardson $\mathrm{M}$, et al. Non -Candida albicans Candida yeasts of the oral cavity. Communicating Current Res Edu Top Tre Appl Microbiol A MendezVilas (Ed.) 2007:719-31.

5. Nneka UC and Ebele OM . The occurrence of oral thrush yeasts among school children in Onitsha Urban, Anambra State, Nigeria. J Med Sci 2005;5(3):177-80.

6. Amir LH .Candida and the Lactating breast : predisposing factors . J Hum Lact 1991;7:177-81.

7. Bensadoun R-J. Patton LL, Lalla $\mathrm{RV}$, et al. Oropharyngeal Candidiasis in head and neck cancer patients treated with radiation. Support Care Cancer 2011;19:737-44.

8. Scully C, el- Kabir M, Samaranayaka LP . Candida and oral candidosis: a review. Crit Rev oral Boil Med 1994;5:125-27.

9. Yehia MM, Ali HYM, AlJammas MA. Oral candidiasis (Thrush) in debilitated children in north Iraq. J Bah Med Society 2004;16(1):28-31.

10. Gupta P, Faridi MMA, Rawat S, et al. Clinical profile and risk factors for oral candidiasis in sick newborns. Ind Ped 1996;33:299- 03.

11. Shrand H. Thrush in the newborn. Br Med J 1961;2:1530-33.

12. Singhi SC, Reddy TC, Chakrabarti A . Oral itraconazole in treatment of candidemia in pediatric: intensive care unit. Indian J Pediatr 2004;71:973-77.

13. Gonzalez - Gravina H , Gonzalez de Moran E , Zambrano O . Oral candidiasis in children and adolescents with cancer . Identification of Candida 
species. Med Oral Patol Oral Bncal 2007;12:419-23.

14. King $\mathrm{RD}$, Lee J, Morrise AL. Adherence of Candida albicans and either Candida species to mucosal epithelial cells. J Infect Immunity 1995;27:667-78..

15.Rowen JL, Rench MA, Kozinetz CA.Endotracheal colonization with Candida enhances risk of systemic candidiasis in very low birth weight neonates. J Pediatr 1994;124:789-94.

16. Karkowska-Kuleta J, RapalaKozik M, Kozik A. Fungi pathogenic to Humans: molecular bases of virulence of Candida albicans, Cryptococcus neoformans, and Aspergillus fumigates. Acta Biochimica Polonica 2009; 56(2):211-24.

17. Mohandas V, Ballal M. Distribution of Candida species in different clinical samples and their virulence: Biofilm formation, proteinase and phopholipase production: a study on hospitalized patients in Southern India . J of Global Infectious Diseases 2011;3(1):4-8.

18. Moris DV, Melhem MSC, Martins MA, et al. Oral Candida species colonization in human immunodeficiency virus infected individuals. J Venom Anim Toxins incl Trop Dis 2008;14(2):224-57.

19. Castilho SD, Rocha MA . Pacifier habit: history and multidisciplinary view. J Pediatr 2009;85(6): 480-89.

20. Belazi M, Velegraki A, Koussidou- Eremondi T, et al. Oral
Candida isolates in patients undergoing radiotherapy for head and neck cancer: prevalence, azoles susceptibility profiles and response to antifungal treatment. Oral Microbiol Immunol 2004;19:347.

21. Li L, Redding S, DongariBagtzoglou A. Candida glabrata, an emerging oral opportunistic pathogen. J Dent Res 2007;86:204.

22. Cannon RD, Holmes AR, Mason $\mathrm{AB}$, et al. Oral Candida: clearance, colonization, or candidiasis? J Dent Res 1995;74:1152.

23. Johnstone HA, Marcinak JF. Candidiasis in breast feeding mother and infant. J Obstet Gynecol Neonatal Nurs 1990;19:171-73. ...

24. Chetty GN, Selvi GS, Kamalan A, et al. Candidiasis in mother and child. Mykosen 1980;23:580-82.

25. Brent NB. Thrush in the breast feeding dyad : results of a survey on diagnosis and treatment. Clin Pediatr 2001;40:503-06.

26. Grimm III SE, Lawrence L, Bailey $\mathrm{J}$, et al. Oral thrush in a one month - old infant: etiology and treatment. Academy of General Dentistry 2011;114(1):1-5. 